\title{
TWO HITHERTO UNNOTICED INDONESIAN BRONZE STATUES OF THE GOD SURYA AND THE GODDESS DURGA
}

The National Museum of Indonesia in Jakarta houses a bronze statue of the goddess Durga (fig. 1) and the Museum Mpu Tantular in Sidoarjo, a bronze of Surya (fig. 2). ${ }^{1}$ As far as I am aware, these images have apparently gone unnoticed in previous studies on Indonesian bronzes. In the catalogue Divine Bronze, published in 1988, Pauline Lunsingh Scheurleer wrote: 'The range of deities represented in bronzes is not the same as that in stone. I know of no bronze representation of the extremely popular Hindu goddess Durga Mahisasuramardini.' It is also said that only two bronze Suryas from ancient Indonesia are known, ${ }^{2}$ one being in the Tropenmuseum in Amsterdam $^{3}$ and the other in the Metropolitan Museum, New York. Another piece preserved in the Los Angeles County Museum of Art should also be added to this list. ${ }^{5}$ I have not found any trace of the Sidoarjo Surya in the later publications at my disposal, but I found the Jakarta Durga briefly mentioned as a unique example of a four-armed Durga in bronze. ${ }^{6}$ It thus seems useful for me to dedicate a note on them to Aziatische Kunst.

Durga and Surya are Hindu deities originating from India but, as with other Indian gods introduced to Southeast Asia, their iconographies were adapted during the process of intercultural exchange with Indonesia. It is assumed that bronze statuettes, being easily transportable, may have played a significant role in this process of exchange. The Durga and Surya images studied here are of particular interest as their iconographies are both rare in ancient Indonesian bronze statuary of the Central and East Javanese periods (8th-14th centuries) and differ from the representations of these deities in stone. Their appearance, inspired by Indian art styles, is also significant in suggesting links between the two areas. In this article, I will first consider the distinctive iconography of these images. I shall then connect them to bronze objects unearthed in southeast Bangladesh, which are likely to be the source of their iconography and art style. Finally, I will compare them to a group of related pieces found in Indonesia to understand their place within ancient Indonesian bronze production and in the broader context of intercultural exchange between South and Southeast Asia.

\section{Iconography}

The feminine bronze divinity preserved in Jakarta (fig. 1) is shown standing in a dynamic posture on a crouching buffalo: her proper left leg on its back, her right leg on its head. She is richly adorned, wears a high bun and has a third eye on her forehead. With her lower right hand she sticks a spear into the animal's flank, while her lower left hand grasps the tip of its tail. Despite the lack of clarity of the attributes held in her upper hands (arrow and bow?), with the help of these characteristics as a whole we can securely identify this image as the goddess Durga in her role as 'slayer of the Buffalo demon' 10:30:51Am 
Fig. 3

Female deity (Durga

or Sarvani?), bronze, found near Banjarnegara, Central Java, Indonesia (exact find-spot unknown), photograph OD 470.

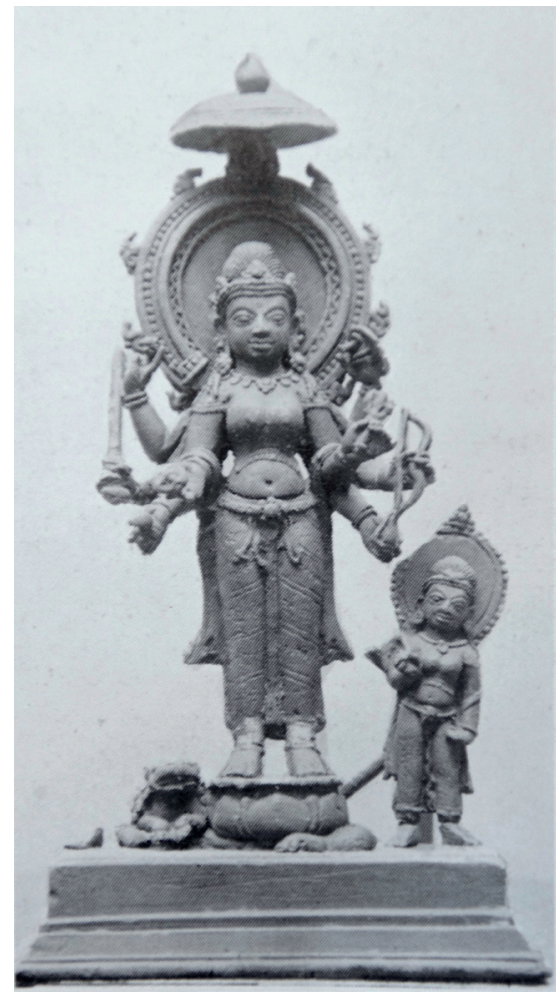

(Skt. Durga Mahisasuramardini). This goddess is well known in ancient Indonesian art as she is often depicted in stone sculpture, but usually the demon emerges in human form from the buffalo's body and the goddess has more than four arms. ${ }^{7}$ The iconographic type of the bronze statue that concerns us here is known from several Indian images dating from the Gupta period (4th-6th centuries) till around the 8th century. ${ }^{8}$ The subsequent type with an anthropo-zoomorphic demon becomes more common from the 8th century onwards. Judging from her iconography, which is still close to early Indian representations, our bronze Durga seems to precede the Indonesian stone images of the goddess. Actually, it may not be the only Durga image in bronze found in Indonesia. Based on her iconographic features, the feminine deity of the photograph OD 470 (fig. 3 ) is probably a representation of Durga or Sarvani (one of Durga's epithets). This form is encountered in ancient Bengal, in which she is depicted without the buffalo but accompanied by her mount, the lion. ${ }^{9}$

The sun god Surya (fig. 2), his arms raised symmetrically in front of his body, holds the stem of an open lotus flower in each hand. His small boots are characteristic of his Indo-Scythian background and he wears a crown as well as a shawl passing over his arms. Two weapons are suspended alongside the pilasters: a sword on his left and an object with a curved extremity on his right. In front of the pedestal are seven elongated shapes that are certainly the heads of the horses that usually pull his chariot. Southeast Asian images identified as Surya almost always hold unopened lotus buds. On the contrary, the image presented here has open lotuses, which is an exceptional but not an entirely isolated instance. It may indeed be compared to the Surat in the 10:30:51Am 

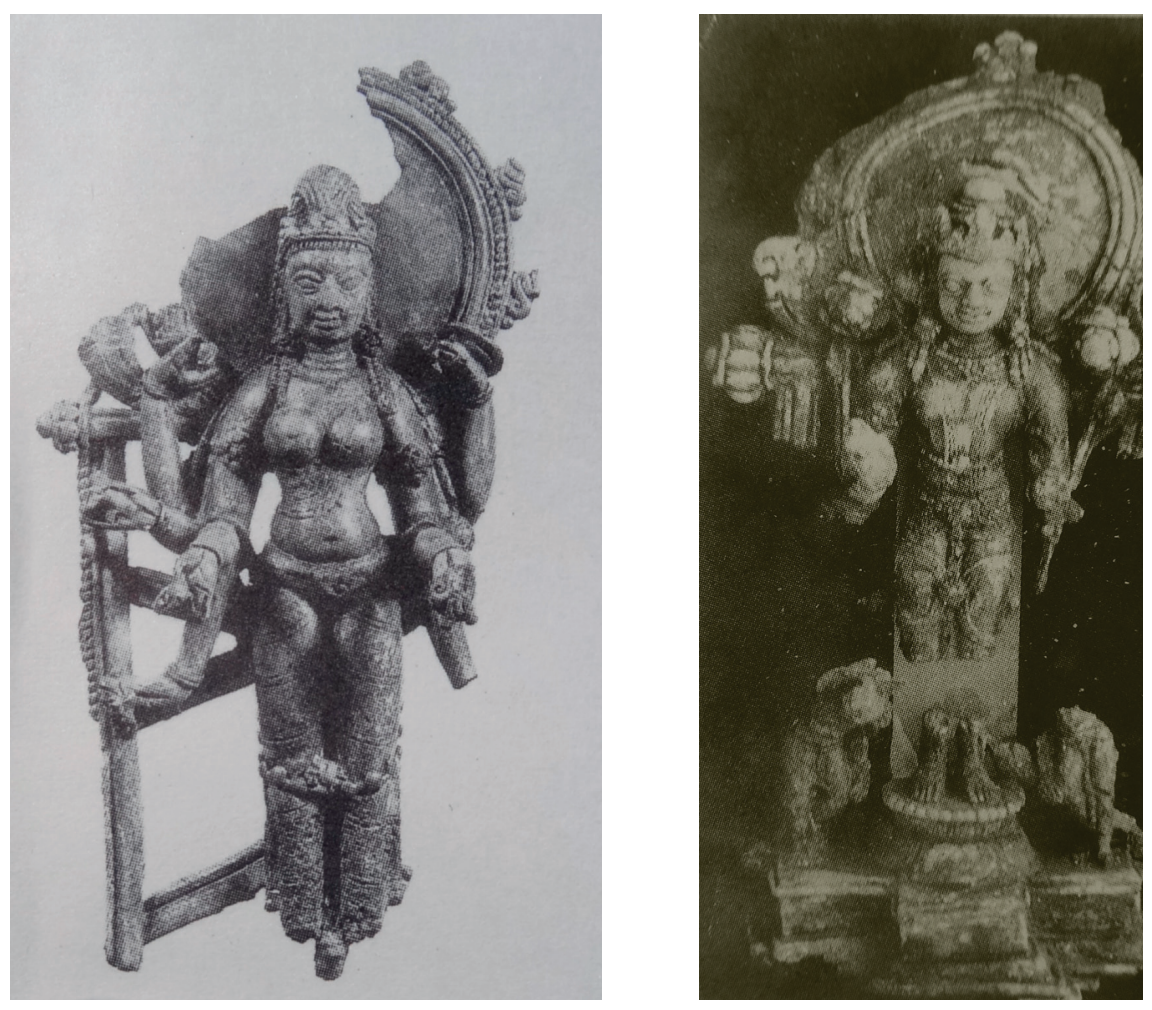

Fig. 4 (left) Female deity, bronze, Lalmai-Mainamati, southeast Bangladesh, ca. 7 th-9th centuries.

Fig. 5 (right) Surya, bronze, LalmaiMainamati, southeast Bangladesh, ca. 7th-9th centuries.
Tropenmuseum (see note 3) and to a Surya in stone in the Musée Guimet. ${ }^{10}$ Although all three images were discovered in Indonesia, their iconography is consistent with Surya sculptures from ancient Bengal. ${ }^{11}$

\section{Relationships between bronzes found in Indonesia and Southeast Bangladesh}

In addition to their rare iconography, the art style of the Durga and Surya bronze statues can also be related to schools of sculpture in ancient Bengal, today divided between Bangladesh and the Indian State of West Bengal. Apart from the important finds at Nalanda and Kurkihar in Bihar, to which Indonesian bronzes were first compared, ${ }^{12}$ scholars have also observed significant resemblances with other vestiges unearthed in Bangladesh, in particular in the current districts of Comilla and Chittagong. ${ }^{13}$ Situated in the southeastern part of Bangladesh, on the border of the old territories of the Pala dynasty (8th-11th centuries), this area was known as Samatata and ruled by other powerful families. Although no historical contact between this region and Indonesia has been recorded in the inscriptions discovered so far, the bronze images constitute archaeological evidence that cultural, artistic and religious exchange did occur.

Comparative studies reveal strong connections between our Durga and Surya and the regional particularities of metal sculptures from the LalmaiMainamati hills, in Comilla district, Bangladesh. Although the bronzes from this area are mainly Buddhist, a few Hindu icons datable to the 7th-9th centuries have been found. Two images published in 1997 (figs. 4 and 5) (14 $^{14}$ can be compared to our Surya and Durga. Alfofour show the figures placed d $_{23}$ 10:30:51Am 
on a round lotus base supported by a rectangular pedestal decorated with mouldings. The lotuses have one or two rows of smooth and heart-shaped petals with intermediate triangular petals and a string of pearls around the

Fig. 6 (p. 31) Visnu, bronze, h. $31 \mathrm{~cm}$, Central Java, Indonesia, ca. 8th-9th centuries, Stichting Nationaal Museum van Wereldculturen Leiden, inv.nr. RV-1403-3322. Photograph: Stichting Nationaal Museum van Wereldculturen. edge. The divine figures are not represented in the round, but are placed against back-slabs (like a relief on a stele), structured by two pilasters supporting a crossbar with ribbed extremities. Round halos, encircled by a row of beads and undulating flames, are placed behind their heads. On either side of the halo, there appears a vegetal motif, and parasols - now missing on figures 4 and 5 - shelter the deities' heads from above.

If we look closely at the details, the Jakarta Durga's waist-cloth is held up by a bejewelled belt and decorated with incised stripes and floral designs, just as we see in figure 4 . The features of their faces are also similar, with large and slightly protruding almond-shaped eyes, delineated by deeply-incised lines. Their necklaces, earrings and diadems are decorated with similar motifs of beads and triangular flowerets, while their hair is equally arranged as a high bun, with twisted locks falling over their shoulders.

The two Surya images shown in figures 2 and 5 both hold open lotuses and wear a crown. Although figure 5 is badly damaged, a strut decorated with a flower is still visible between Surya's left foot and his attendant's body. The space between the pilasters and the image was filled in with herringbonelike struts, as was the case on figure 4 . This type of open-worked rear plate resembles the back-piece of the Surya found in Indonesia.

\section{Related bronze sculptures found in Indonesia}

Several bronze statuettes found in Indonesia that share similar characteristics are preserved in various European and Indonesian collections. While all of them have similarly structured back-rests and standing divine figures, variations in the treatment of the details and iconography show that they have different places of origin. It is often difficult to pinpoint precise areas of contact, but in the case of southeast Bangladesh, bronze statuettes that were most likely imported from this area have been found in Indonesia, probably brought by pilgrims, travellers and traders along the maritime trade routes. A Visnu in the Leiden Museum voor Volkenkunde and a Surya in the Tropenmuseum, both belonging to the sub-group studied here, have been identified as images from southeast Bangladesh by previous scholars. ${ }^{15}$ I believe this is also the case for the possible Durga of the photograph OD 470 (fig. 3), as well as for two Siva-Parvati couples in the National Museum in Jakarta. ${ }^{16}$

For other images in this sub-group, as is the case for our Surya, their origin is less clear. We lack similar comparative examples that might help us to determine whether they came from southeast Bangladesh or whether they are the work of Indonesian craftsmen closely following an Indian model. Often, only tiny details enable us to see the difference. In previous studies, the back-slabs with struts have been pointed out as a determining feature in recognizing an object from the Indian subcontinent because it seemed that Indonesian craftsmen only made closed back-slabs. ${ }^{17}$ By enlarging the corpus, I am able to suggest that this observation may not be true.

Our bronze Surya may well be an Indonesian creation using the Indian method of an open-worked back-slab (fig. 2). Despite its resemblance to figure 5 from Lalmai-Mainamati, variations in the details are just as

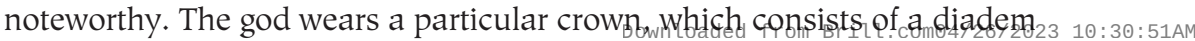




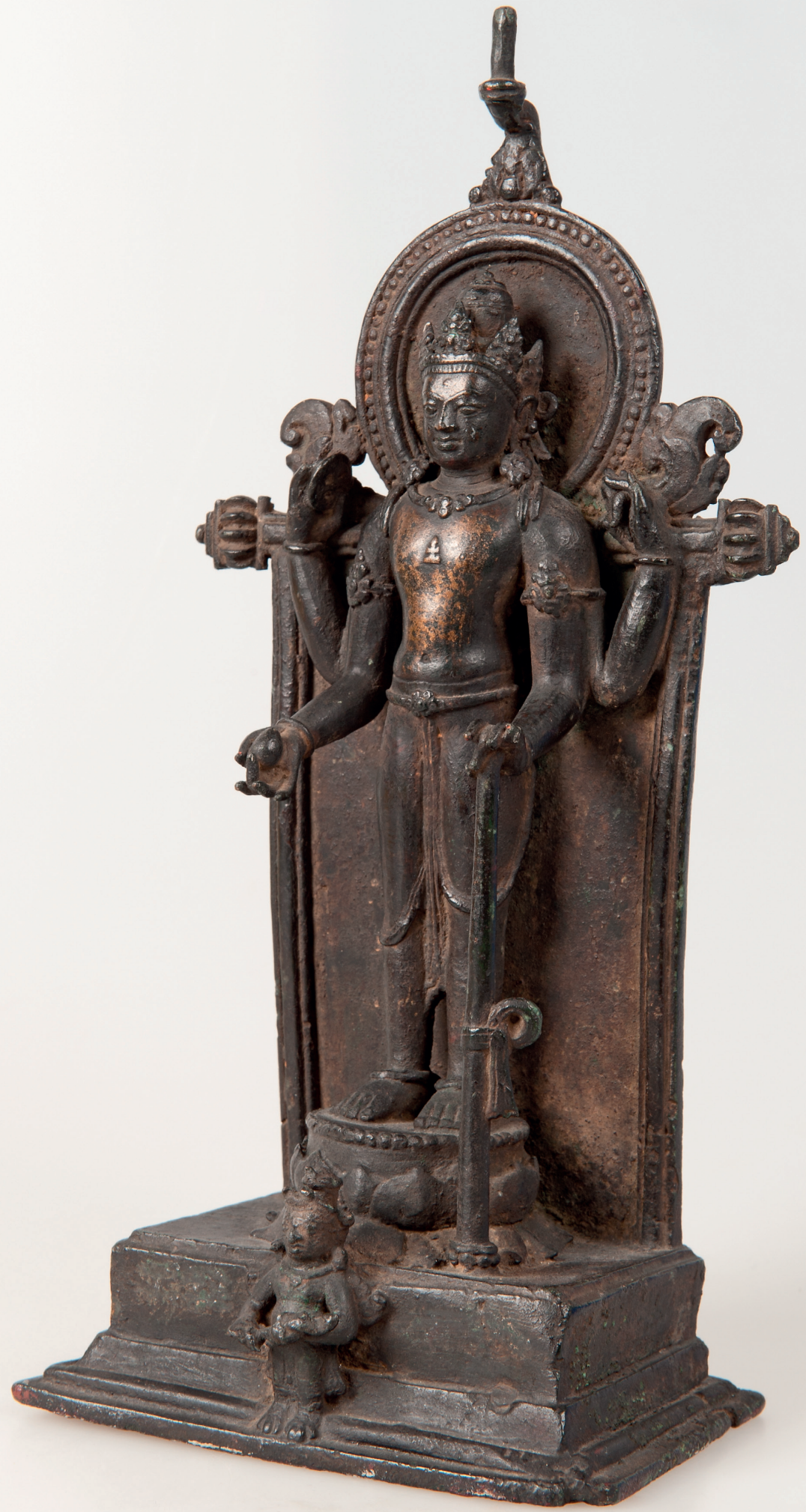


with bejewelled flowerets and, at the top of the head, a cylinder with a flaring rim topped by a central bulb. This cylinder form is different from the well-developed dome-shaped crown of figure 5, characteristic of southeast Bangladesh, but it is visible - though with slight variations - on other Southeast Asian Surya and Visnu images and could be a Southeast Asian creation. ${ }^{18}$ The same can be said of the parasol supported by a bent handle, since this feature is never seen on Indian bronzes. ${ }^{19}$ Three other images may be Indonesian despite their open-work back-piece. ${ }^{20}$

Finally, together with figure 1, other images illustrate different stages of evolution leading to the elaboration of local iconographies and a style that departs more clearly from Indian prototypes. ${ }^{21}$ Durga's iconography is still close to Indian representations of the goddess, but the art style betrays her Indonesian origin. The back-slab is closed by a sheet of metal and the surface is smooth on the reverse, contrary to Indian images which normally bear sculpted elements. Moreover, the deity is not completely attached to the back-slab and was thus probably cast separately, unlike the common Indian casting process seen on the Lalmai-Mainamati bronzes. ${ }^{22} \mathrm{~A}$ bronze Visnu kept in Leiden is comparable (fig. 6). It is closely related to Indian models, but the plain back-piece and the bent handle of the parasol show its Indonesian origin.

These Durga and Surya statues are thus part of a group of Indonesian images possibly dating from around the 8th century, whose prototypes from Southeast Bangladesh are now well established. They show that bronze images of these divinities were probably more numerous than previously assumed in Indonesia, even if only a few examples have come down to us. By illustrating a transitional phase - which led, through distinct stages of selection and adaptation, to the constitution of local iconographies and styles - they contribute to our knowledge of the history of cultural exchange between South and Southeast Asia.

- Mathilde Mechling is a Ph.D. student at University Sorbonne Nouvelle-Paris 3 and Leiden University. She is working on the Hindu-Buddhist bronze statuettes from Indonesia in relation to their cultural, religious and artistic contexts.

\section{Literature}

A. J. Bernet Kempers, The Bronzes of Nalanda and Hindu-Javanese Art, Brill, Leiden, 1933.

Albert Le Bonheur, La sculpture indonésienne au Musée Guimet: catalogue et étude iconographique, Presses universitaires de France, Paris, 1971.

Robert L. Brown, 'Sun God Surya', South and Southeast Asian Art: an online scholarly catalogue at LACMA, Los Angeles County Museum of Art, Los Angeles, 2013. http:// seasian.catalog.lacma.org (last consulted May 2015).

Jan Fontein (ed.), The sculpture of Indonesia, National Gallery of Art, Washington, 1990. [exh. cat.]

Enamul Haque, Bengal Sculptures: Hindu Iconography up to c. 1250 A.D., Bangladesh National Museum, Dhaka, 1992.

Enamul Haque and Adalbert J. Gail (eds.), Sculptures in Bangladesh: An Inventory of Select Hindu, Buddhist and Jain Stone and Bronze images in Museums and Collections of Bangladesh (up to the $13^{\text {th }}$ Century), The International Centre for Study of Bengal Art, Dhaka, 2008.

A. B. M. Husain, Mainamati-Devaparvata, Asiatic Society of Bangladesh, Dhaka, 1997. 
Martin Lerner, Bronze sculptures from Asia, Metropolitan Museum of Art, New York, 1975. [exh. cat.]

J.E. van Lohuizen-de Leeuw, Indo-Javanese Metalwork, Linden-Museum, Stuttgart, 1984. Pauline Lunsingh Scheurleer, 'Een perfect paar', Aziatische Kunst 38/3 (2008), pp. 44-54. Pauline Lunsingh Scheurleer, 'Bronze images and their place in ancient Indonesian culture', in: P. Lunsingh Scheurleer and M. J. Klokke (eds.), Ancient Indonesian Sculpture, KITLV Press, Leiden, 1994, pp. 76-97. [Verhandelingen 165]

Pauline Lunsingh Scheurleer and Marijke J. Klokke, Divine Bronze: Ancient Indonesian Bronzes from A.D. 600 to 1600, Brill, Leiden, 1988. [exh. cat.]

Hariani Santiko, Bhatari Durga, Fakultas Sastra Universitas Indonesia, Depok, 1992.

The Huntington Archive: http://huntington.wmc.ohio-state.edu/public/index.cfm (last consulted May 2015).

\section{Notes}

* I would like to thank my two supervisors, Marijke Klokke and Vincent Lefèvre, as well as Arlo Griffiths, for their suggestions and advice.

1. I recently encountered these bronze images during a stay in Indonesia from March to May 2014. I am deeply indebted to the Director and staff of the National Museum of Indonesia in Jakarta who facilitated my access to the bronze collection. I would like to thank them here for their kindness.

2. Lunsingh Scheurleer and Klokke 1988: 18 and 19. Several bronze images of Durga have been recorded, but these are forgeries; see the list given by Lunsingh Scheurleer 1994: 87, n. 8. Further in this paper, I will mention a second possible Durga (OD 470) that is not a forgery (fig. 3).

3. Lunsingh Scheurleer and Klokke 1988: cat. 15 (inv.nr. 1431-1a).

4. Lerner 1975: pl. 12 (inv.nr. 1987.142.20).

5. Brown 2013: fig. 1 (inv.nr. M.79.189.9).

6. Santiko 1992: 31, 33, fig. 6.

7. See, for example Fontein 1990: cat. nr. 22 and 23.

8. See, for example, the Durga depicted on Cave 17 at Ellora (ca. 6th-7th centuries) and from Bhumara, Allahabad Museum inv.nr. 152 (Huntington Archive scan. nr. 0007986: http://huntington.wmc.ohio-state.edu/public/index.cfm?fuseaction=show ThisDetail\&ObjectID=9452; and 0001426: http://huntington.wmc.ohio-state.edu/ public/index.cfm?fuseaction=showThisDetail 8 ObjectID=2892).

9. Haque 1992: 214.

10. Le Bonheur 1971: 270-1 (inv.nr. 18 239).

11. Haque and Gail 2008: 44, pls. 305-12.

12. Bernet Kempers 1933.

13. Lunsingh Scheurleer and Klokke 1988: 28.

14. Husain 1997: 186, 195 (lower left and right).

15. Lunsingh Scheurleer and Klokke 1988: cat. 14 (RMV inv.nr. 1403-2837) and see n. 3 above.

16. Inv.nr. 8442-c.18 - apparently unpublished - and inv.nr. 518b/3657. See Lunsingh Scheurleer 2008: 51, fig. 6 (inv.nr. 518b/3657 attributed to Northeast India).

17. For example, Lunsingh Scheurleer 1994: 79.

18. As suggested by Brown 2013.

19. Lunsingh Scheurleer and Klokke 1988: 30.

20. National Museum Jakarta: Visnu (inv.nr. 485/c.28), Siva (inv.nr. 493/c.12.), Brahma (inv.nr. 8403/c.19).

21. Fontein 1990: cat. 51 (Balai Pelestarian Cagar Budaya, Bogem); Lunsingh Scheurleer and Klokke 1988: cat. 22 (RMV inv.nr. 1403-2839); van Lohuizen-de Leeuw 1984: cat. 30 (Linden-Museum inv.nr. 18 540); Bernet Kempers 1933: fig. 33 (RMV inv.nr. 1403-3322).

22. Husain 1997: 194. 


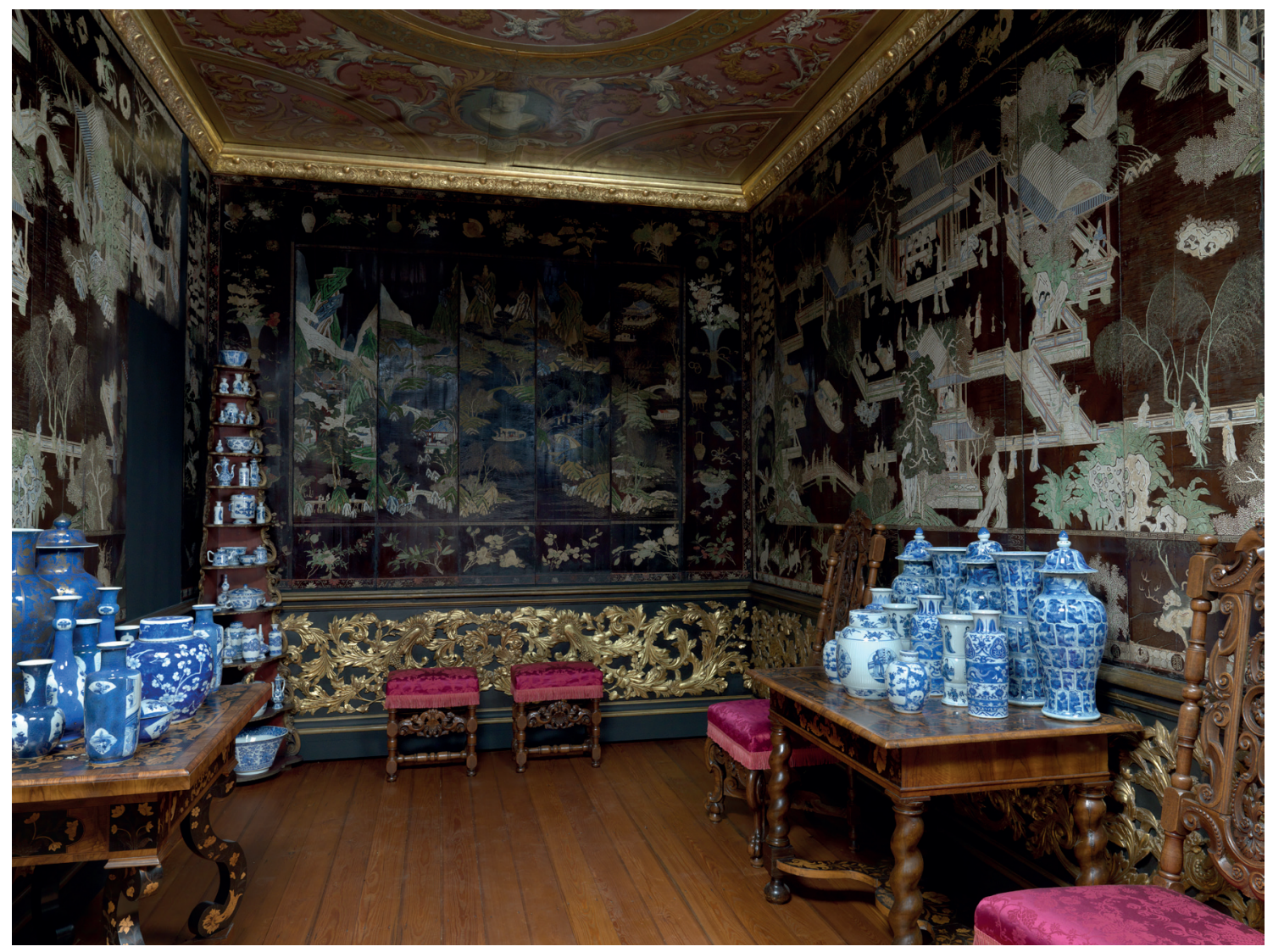

Afb. 1

Lakkamer van kuan

cai lak en verguld

lindehout, 514 × 305,9 X

$295,6 \mathrm{~cm}$., Leeuwarden,

voor 1695 , Rijksmuseum

Amsterdam, inv.nr.

BK-16709, foto na

behandeling. 